\title{
Municipal policy enabling regional food systems in British Columbia, Canada: Assessing focal areas and gaps
}

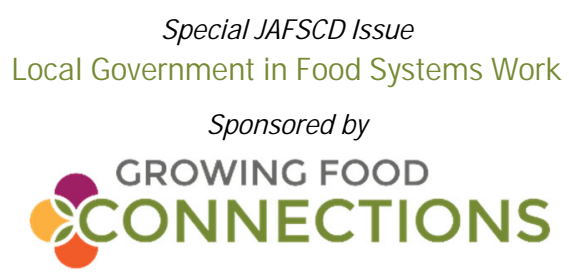

Naomi Robert ${ }^{a *}$ and Kent Mullinix ${ }^{b}$

Institute for Sustainable Food Systems, K wantlen Polytechnic University

Submitted November 15, 2017 / Revised January 4, January 22, and May 14, 2018 / Accepted May 14, 2018 /

Published online O ctober 17, 2018

Citation: Robert, N., \& Mullinix, K. (2018). Municipal policy enabling regional food systems in British Columbia, Canada: Assessing focal areas and gaps. Journal of A griculture, F ood Systems, and C ommunity D evelopment, 8(Suppl. 2), 1-18. https:/ / doi.org/ 10.5304/ jafscd.2018.08B.003

Copyright @ 2018 by the Authors. Published by the Lyson Center for Civic Agriculture and Food Systems. Open access under CC BY license.

\begin{abstract}
Local-regional food systems are increasingly the focus of community activism and local government planning in British Columbia (BC), Canada. At present, there is no provincial or federal government food system strategy to inform or guide local government policy efforts. To ascertain focal points of local government food system planning, we assessed current municipal Official Community Plans (OCPs) in BC and suggest areas for future policy development to enable regional food systems in the province. In $\mathrm{BC}$, an OCP is the most comprehensive, high-level municipal planning document used to guide future management and land use decisions. We reviewed OCPs from 61
\end{abstract}

a $*$ C orresponding author: Naomi Robert, Institute for Sustainable Food Systems, Kwantlen Polytechnic University; 8771 Lansdowne Road, Richmond, BC, Canada; Naomi.robert@ kpu.ca

b Kent Mullinix, Institute for Sustainable Food Systems, K wantlen Polytechnic University; 8771 Lansdowne Road; Richmond, BC, Canada; Kent.mullinix@kpu.ca municipalities (37\% of BC's municipalities) and categorized the food systems policy within according to a set of 13 topics and 53 subtopics. We report policy topic or subtopic frequency, expressed as a percentage of municipalities $(n=49)$. We also developed and applied a framework to identify policy gaps for enabling regional food systems. Policy addressing food access for residents as well as policy supporting urban agriculture were identified as the most prevalent food system policy foci in BC. Recognition of and support for Indigenous foodways, however, were scarcely addressed by existing food access policies. We identified gaps in regional food system policy regarding postproduction capacity for regional markets, waste management, and environmental stewardship. We offer that fostering regional systems requires coordinated policy efforts between jurisdictions and suggest that such coordination is particularly important and needed between urban and rural municipalities, which represent primary food-consuming and food-producing areas, respectively. This coordination will require 
municipalities to expand food system policy efforts beyond their current urban agriculture focus, which has been criticized as having a limited capacity to address a number of pressing food system concerns. The framework we developed and applied can serve as a tool in other jurisdictions to assess current local government regional food system policy foci and identify areas for future policy development to enable regional food systems.

\section{Keywords}

Official Community Plans; Food System Policy; Food Planning; Regional Food Systems; Policy Categorization; Local G overnment; Policy Gaps; British Columbia; Canada

\section{Introduction}

Our highly globalized industrial food system is criticized for delivering detrimental environmental, economic, and social outcomes while largely externalizing the associated costs of these outcomes. These include, but are not limited to, the economic and social marginalization of farming, the loss of farmers, the consolidation of farms, the hollowing out of rural communities, corporate hegemony, the loss of habitat and biodiversity, water and air pollution, soil degradation, increased occurrence of dietrelated diseases, and unjust working conditions for farmworkers (Clapp, 2012; International Panel of Experts on Sustainable Food Systems [IPE S Food], 2017; Nestle, 2002; Patel, 2008). Within this food system, $11 \%$ of the global population is undernourished, while an equal proportion is obese (Food and Agriculture O rganization of the United Nations [FAO ], 2017; World Health O rganizaton [WHO], 2017). These externalized costs are often obfuscated by long supply chains that disconnect food system actors from one another (Clapp, 2012). Simultaneously, the majority of wealth generated from this food system accrues to a small number of largely transnational corporations, distant physically, economically, and socially from the regions and people most affected by food system externalities (Clapp, 2012; IPE S, 2017). The localization or regionalization of food systems is offered by many as a remedy, in whole or part, for these undesirable and unnecessary outcomes (Cleveland, Müller, Tranovich, Mazaroli \& Hinson,
2014; Harris, Nixon, Newman, \& Mullinix, 2016; Mullinix et al., 2016).

Conversely, food system localization has been criticized for oversimplifying the relationship between scale and food system outcomes. Born and Purcell (2006) describe this as the "local trap" and caution against directly relating the scale of food consumption to desirable outcomes, such as social justice or environmental stewardship. O thers, however, suggest that a place-based food system, which operates within the constraints and per the demands of the region in which it functions, is better positioned to remedy social, economic, and environmental concerns (Klassen \& Wittman, 2017; Mullinix et al., 2016). Per the latter perspective, local governments, food sector actors, and community and social organizations are increasingly working to advance local-regional food systems. However, food systems planning has been largely excluded from local government planning efforts throughout the 20th century (APA, 2007; Morgan, 2009; Pothukuchi \& Kaufman, 2000), and municipal level food system planning in BC is still in nascent stages, as it is elsewhere in North America.

In $\mathrm{BC}$, food and agriculture have traditionally been viewed as the purview of the provincial/ national government. However, many of the impacts of poor or absent food system planning-inadequate access to food for residents, local pollution, waste management, loss of agricultural land and rural livelihoods--are most acutely felt at the local government level (MacRae \& D onahue, 2013). As such, including food systems as a fundamental component of community and regional planning presents a substantial opportunity to improve public health as well as the ecological and economic wellbeing of communities (American Planning Association [APA], 2017; Clark, Freedgood, Irish, Hodgson, \& Raja, 2017; Morgan, 2009; Y oumans, 2014).

O pportunities for M unicipal Food Systems Planning in $\mathrm{BC}$

The potential impact of local government planning on food systems holds true in British Columbia (population 4.6 million). For example, while agricultural land in $\mathrm{BC}$ is held within the Agricultural 
Land Reserve (ALR), a provincial land use zone restricting the nonfarm use of agricultural land (Agricultural Land Commission [ALC], 2002), individual municipalities have considerable influence over how provincial ALR regulations are implemented and enforced. While provincial guidelines for local government bylaw standards exist for a variety of land use activities, (British Columbia Ministry of Agriculture [BC MoA], 2015a; 2015b), agricultural land use regulations vary among $\mathrm{BC}$ municipalities. For example, the Corporation of D elta and the Township of Langley are two municipalities in Metro Vancouver with at least $50 \%$ of their land base in the ALR (BC MoA, 2014; Stats Canada, 2011). D elta's zoning bylaw limits the footprint of residential uses (house, driveway, etc.) on farmland to $38,800-53,800 \mathrm{ft}^{2}$ $\left(3,600-5,000 \mathrm{~m}^{2}\right)$ and the floor area of the farmhouse itself to 3,550-5,005 $\mathrm{ft}^{2}$ (330-465 m²) depending on the parcel size (Corporation of Delta, 1979). In contrast, the Township of Langley's zoning does not restrict the residential footprint or farmhouse floor area on agricultural land commensurate with urban areas (Township of Langley, 1987).

Regional food systems also represent economic development opportunities for communities. British Columbians spend an estimated CA $\$ 17$ billion on food annually (Statistics Canada, 2015; 2016). Most of this expenditure is for imported food and nonlocal food businesses, whereby the vast majority of these dollars leave the community by the end of the business day (Heffernan, 2006). As such, promoting businesses to provide, and residents to purchase and consume, regional foods presents a significant economic opportunity for municipalities. Capturing a greater portion of food expenditures locally can allow capital to change hands several times before leaving the community, multiplying the economic benefits for the region (Heffernan, 2006; Mullinix et al., 2016).

O fficial Community Plans and F ood Systems Planning In British Columbia, local governments develop OCPs to outline the objectives and policies that will guide planning and land use management decisions. OCPs are most frequently developed by local government planning staff or contracted to planning consultants with stakeholder input. As comprehensive plans, OCPs stem from the understanding that issues such as urban design, social and economic development, community health, and the environment cannot be addressed in isolation (Hodgson, 2012; Neuner, Kelly, \& Raja, 2011). OCPs act on a temporal scale of years to decades, and local government policies can benefit from "greater buy-in and longevity" when they take direction from an OCP (Youmans, 2014, p. 4). OCPs do not obligate or authorize local governments to advance particular initiatives; however, subsequently adopted bylaws must be consistent with the OCP (G overnment of British Columbia, 2015). In this way, O CPs provide longterm direction for community development and, given the impact of food systems on a myriad of issues intrinsic to community planning, are an appropriate vehicle for food system planning.

Local governments can address food policy in other forms than OCPs (e.g., sustainability strategies, regulatory bylaws, zoning, etc.). However, given their mandate, planning timeframe, and ubiquity across all $\mathrm{BC}$ municipalities, OCPs are the most appropriate platform to evaluate how food systems are being incorporated into high-level local government policy across the province. The City of Vancouver is an exception, where numerous Neighbourhood Plans are substituted for a single OCP.

Local government food system planning efforts in $\mathrm{BC}$ have increased considerably in recent years (Institute for Sustainable Food Systems [ISFS], 2017). Relatively detailed food system strategies have been developed at the local (City of Vancouver, 2013; Selkirk Planning and D esign \& Ross, 2014) and regional levels (CRD , 2016; Metro Vancouver, 2011) and a number of municipalities and regions have adopted food charters with guiding food system value statements or goals (City of Richmond, 2016; Cowichan G reen Community, 2009; North Shore Table Matters, 2013). OCPs, however, are among the most widely used vehicle to include high-level food system policy within local government (ISFS, 2017). While food systems are gaining the attention of planners in $\mathrm{BC}$, concerns have been raised over a lack of coordination in food system planning (MacRae, 1999; Sussmann 
\& Feeney, 2015). In BC, like many regions in Canada and abroad, there is little direction from provincial or federal governments to guide food system planning. (Although a national food system policy is currently under development in Canada [Finnigan, 2017].) Subsequently, local governments are embarking on food system planning initiatives without a common vision. Such coordination will be critical for advancing regional food systems, particularly between rural and urban municipalities, which represent the primary food-producing and food-consuming regions, respectively. Furthermore, sharing food system planning strategies across regions has been identified as a priority for advancing sustainable food systems in BC (Sussmann \& Feeney, 2015). This study, therefore, is a step toward understanding the current status and priorities of municipal food systems planning in $\mathrm{BC}$, noting where and how plans differ between rural and urban communities, and suggesting a high-level direction for local governments to advance regional food systems.

Previous studies of local government food systems planning in Canada have focused on assessing the capacity and contributions of specific planning tools and agencies in advancing local government food system goals (MacRae \& Donahue, 2013), such as Food Policy Councils (Fridman \& Lenters, 2013; Schiff, 2007) and Municipal Food Strategies (Fridman \& Lenters, 2013; Mansfield \& Mendes, 2013). While case studies have assessed the local government food system policy of single municipalities (Mills, 2011), very few have examined the cumulative body of municipal food planning efforts in OCPs to characterize policy priorities and direction in the province (Y oumans, 2014), and none have done so by comparing the policy priorities of urban and rural communities. As such, taking stock of the current foci for local government food planning in BC, examining how they differ between urban and rural municipalities, and identifying areas for future policy development is a timely contribution to advancing our understanding of the current direction of food system planning and charting next steps.
Study 0 bjectives

Given the opportunity for OCPs to establish planning directives for future development, the recent increase in attention to food system planning at the local government level in $\mathrm{BC}$, the lack of policy coordination between regions, and the need to better understand food system planning strategies in the province, our study aimed to:

(1) Identify the current food system policy foci in high-level, long-term municipal policy in BC;

(2) Assess how these foci support foundational elements of regional food systems;

(3) Assess if and where policy discrepancies exist between urban and rural communities in terms of policy-level support for foundational elements of regional food system; and

(4) Identify gaps for future policy development to foster regional food systems.

\section{Methods}

Policy Categorization and $\mathrm{E}$ valuation of $\mathrm{F}$ od To code policy, we identified 13 topic categories reflective of the various dimensions of the food system (e.g., food access, waste management) that are commonly addressed in OCPs. Topic categories were informed by the thematic groupings employed in literature evaluating food system plans (Evans-Cowley, 2011; Hodgson, 2012; Youmans, 2014) as well as emerging areas of importance in food system policy, such as Indigenous foodways (Capital Regional D istrict [CRD ], 2016; Food Secure Canada [FSC], 2015). We then generated a list of 53 subtopics under the 13 topic categories. Subtopics provided further detail as to how a policy was addressing a given topic category. For example, the policy topic 'improve access to food for residents' was assigned the subtopics "direct marketing," "access to affordable/ nutritious food," "access to food retail locations (not direct marketing)," "emergency food sources," "community kitchens," and "local procurement." Appendix A presents the complete categorization system we employed to code 
municipal food systems policy. All policies were coded with a minimum of one topic category. Similar to Y oumans' (2014) coding system, subtopic categories were assigned in addition to a topic category only if a policy addressed a given topic beyond a general statement of support. If policies directly addressed more than one topic/ subtopic, then multiple topic/ subtopic categories were assigned accordingly.

To determine policy foci, we assessed the frequency of occurrence for each policy topic, expressed as a percentage of municipalities $(\mathrm{n}=49)$. Food system policy topics were deemed as widely, moderately, or scarcely represented if they were addressed in more than $50 \%$, between $50 \%$ and $11 \%$, and $10 \%$ or less of $0 \mathrm{CPs}$, respectively. To assess topic representation between urban and rural municipalities, municipalities were divided into two groups according to population density (Statistics Canada, 2011). Rural municipalities were defined as having population densities of less than 1,036 people/ mi2 (400 people/ km²) (Statistics Canada, n.d.). Municipalities with population densities equal to, or exceeding this threshold were characterized as urban.

\section{Policy Review and Rationale}

This study required food system policy from local government OCPs to be systematically reviewed, thematically coded, and tabulated. Food system policy was defined as any directive related to food systems that addressed a component of the food supply chain. Additionally, directives that touched on food systems in the context of education, economic development, planning or policy, and water management were included.

Selection of municipalities for our OCP policy review was based on geographic location and population size, prioritizing population centers in the province. For this we used D evelopment Regions, an administrative boundary formed from aggregated Regional Districts (British Columbia D evelopment Regions, n.d.), to divide the province into eight geographic regions. We then reviewed the OCPs of the two municipalities with the greatest populations within each Development Region. Selection methodology favored municipalities likely to have the resources (e.g., food policy councils, dedicated social planners, etc.) to progressively address aspects of food system planning. However, given the uneven population distribution in the province, selecting population centers within each D evelopment Region still allowed for the inclusion of rural communities in the policy review. The Lower Mainland/ Southwest D evelopment Region, the most populous area of the province, was an exception to this methodology. In this region, all 34 municipalities were included in the review. The OCPs from an additional 13 municipalities were reviewed because they were identified as incorporating a notable focus on food systems. OCPs currently being updated were excluded (e.g., City of Fort St John). Additionally, the City of Vancouver was excluded from the study because the municipality substitutes multiple neighborhood plans for a citywide OCP. Thus, our sampling methodology was not random, but systematically designed to survey and maximally capture $\mathrm{BC}$ regional food system enabling policy.

OCPs from 61 of a total of $162 \mathrm{BC}$ municipalities (37\%) were reviewed for food policy (Figure 1). This included municipalities with varying geographic and demographic characteristics, while recognizing the tendency of population centers to contribute more frequently and fulsomely to food system policy development. We therefore believe that food policy compiled from these municipalities is reasonably representative of $\mathrm{OCP}$ food policy in BC.

Inclusion Criteria and F ood Policy Tabulation Policies within OCPs that explicitly addressed food systems were compiled and subject to inclusion criteria prior to categorization. Inclusion criteria were designed to ensure that the content of food policies included in the analysis (1) extended beyond recognition of existing standards and (2) included planning objectives transcending a single, isolated action. If the assessment of either criterion was 'yes' for a given OCP policy, then that policy statement was excluded from the analysis (Table 1). After the inclusion assessment, 12 municipal OCPs were excluded, and the final compilation of OCP food policy for analysis totaled 49 municipalities (30\% of BC's municipalities). 
A Framework for A ssessing Regional Food Systems Policy

We presumed that a regional food system - characterized by shorter supply chains - must have the capacity to connect food production to regional consumers. We recognized that in order for such a food system to achieve the sustainability outcomes routinely proffered, it must also advance environmental stewardship, improve equity among food system actors, and reduce and reclaim food-related waste (Feenstra, 2002). We thus propose that regional food systems must emphasize the following five elements: (1) food production and postproduction capacity focused on regional markets (Bell, 2010; G win \& McCann, 2017); (2) economic viability of the agricultural sector (Jablonski, Hendrickson, Vogel, \& Schmit, 2017); (3) access to healthy, nutritious, and culturally appropriate food for all citizens (D esjardins, 2010; Morland, 2015; Morrison, 2008); (4) food system waste management (Morone, Papendiek, \& Tartiu, 2017); and (5) environmental stewardship (Warshall et al., 2002). Table 2 outlines these five foundational elements of regional food systems and the corresponding food system policy topics used in this analysis. We therefore
Figure 1. Distribution of British Columbia Municipalities with Official Community Plans (OCPs) Included in the Analysis

Rural municipalities (population density $<400$ people $/ \mathrm{km}^{2}$ ) are in blue and urban municipalities (population density $\geq$ to 400 people $/ \mathrm{km}^{2}$ ) are in orange.

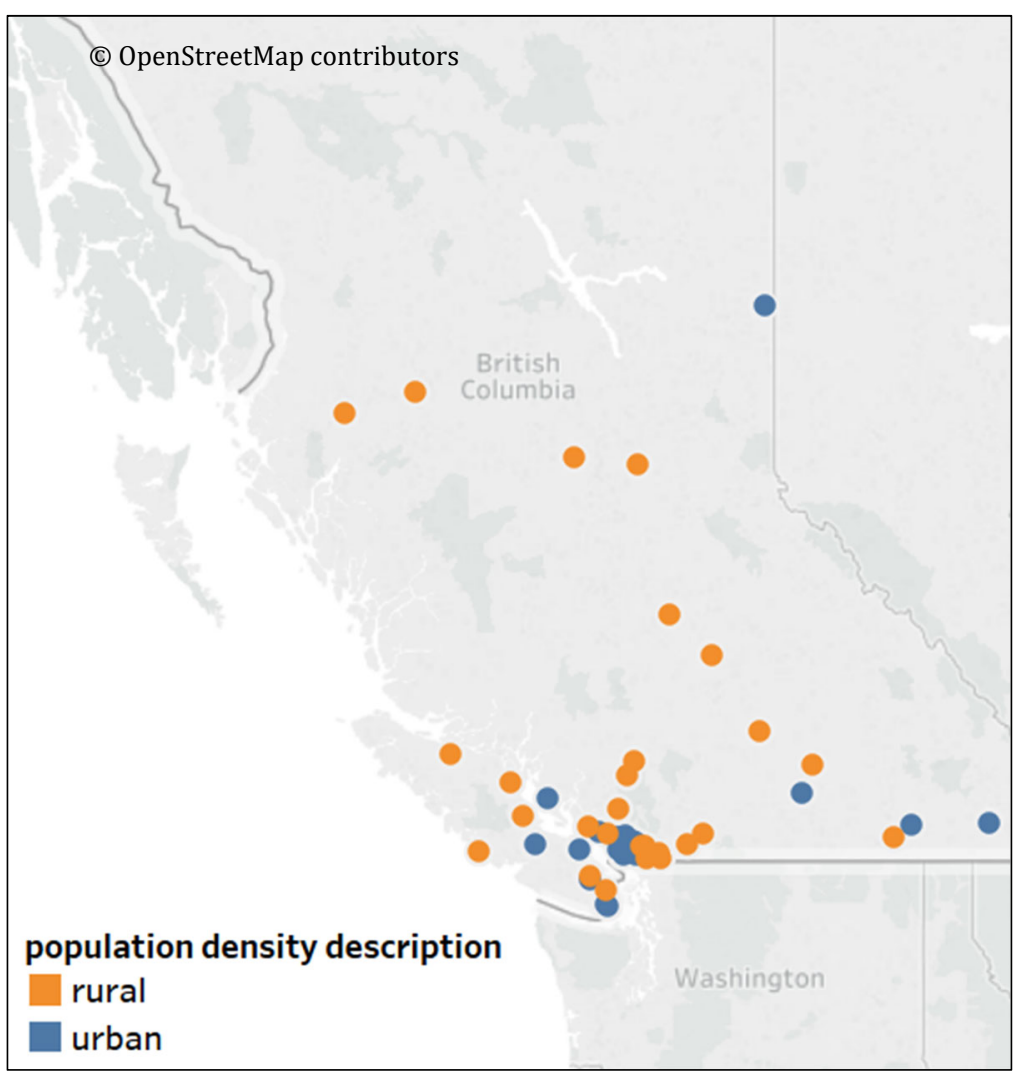

Data source Statistics Canada, (n.d). Map data available under Open Database License: http://www.openstreetmap.org/copyright

assumed that food system policy seeking to enable regional food systems should address these

Table 1. Examples of Food Policy Statements Included and Excluded According to Inclusion Criteria

\begin{tabular}{cll}
\hline \multirow{2}{*}{$\begin{array}{c}\text { Selection Criteria } \\
\text { Outcome }\end{array}$} & $\begin{array}{l}\text { Is the policy limited to confirmation of and/or } \\
\text { compliance with an existing required standard or } \\
\text { limited to a reference to another piece of policy? }\end{array}$ & $\begin{array}{l}\text { Does the policy support a single action or } \\
\text { occurrence rather than provide guidance for } \\
\text { municipal decision making in the future? }\end{array}$ \\
\cline { 2 - 3 } Yes $\Rightarrow$ Exclude & $\begin{array}{l}\text { E.g., all subdivision of Agriculture Land Reserve } \\
\text { land must be in accordance with the Agricultural } \\
\text { Land Commission Act and regulations. }\end{array}$ & $\begin{array}{l}\text { E.g., create a soil management guideline for } \\
\text { community gardens. }\end{array}$ \\
\hline \multirow{2}{*}{ No $\Rightarrow$ Include } & $\begin{array}{l}\text { E.g., support the farming integrity of the Agricul- } \\
\text { ture Land Reserve land by encouraging the }\end{array}$ & $\begin{array}{l}\text { E.g., support urban agriculture initiatives and } \\
\text { the development of resources to improve on-site } \\
\text { consolidation of small parcels to support } \\
\text { economically viable farm units. }\end{array}$ \\
\hline
\end{tabular}


Journal of Agriculture, Food Systems, and Community D evelopment ISSN: 2152-0801 online

https:/ / www.foodsystemsjournal.org

foundational food system elements, and we used this framework to make recommendations for areas of future policy development in British Columbia.

\section{Results and D iscussion}

\section{Food System Policy Foci}

Five food system policy topics were identified as widely represented (Figure 2), and therefore constitute areas of current policy focus. They were, (1) improve access to food for residents (67\%); (2) support for urban agriculture (67\%); (3) protect agricultural land and promote its use for agriculture
(65\%); (4) support the economic viability of the agricultural sector (61\%); and (5) support for edge (interface of urban and agricultural activities) planning and urban conflict mitigation (55\%).

Six moderately represented topics were identified. They were (1) support for food system education and research (45\%); (2) support for food system policy partnerships, advocacy, and development (45\%); (3) support and build capacity for postproduction activities and industry (41\%); (4) support ecosystem protection and enhancement in food systems (41\%); (5) improve food system waste management (39\%); and (6) improve water management in food systems (39\%).

Table 2. The Five Foundational Elements of Regional Food Systems and Corresponding Food System Policy Topics

\begin{tabular}{ll}
\hline Foundational Element & Corresponding Food System Policy Topics \\
\hline $\begin{array}{ll}\text { Food production and postproduction } \\
\text { capacity for regional markets }\end{array}$ & Protect agricultural land and promote its use for agriculture \\
\cline { 2 - 2 } Economic viability of agricultural sector & Support and build capacity for local postproduction activities and industry \\
\hline $\begin{array}{l}\text { Access to healthy, nutritious, culturally } \\
\text { appropriate food for all citizens }\end{array}$ & Improve access to food for residents \\
\cline { 2 - 2 } & Support Indigenous foodways \\
\hline Food system waste management & Improve food system waste management \\
\hline $\begin{array}{l}\text { Environmental stewardship within the } \\
\text { food systems }\end{array}$ & Support ecosystem protection and enhancement in food systems \\
\hline
\end{tabular}

Figure 2. Representation of Food System Policy Topics in Official Community Plans ( $n=49)$

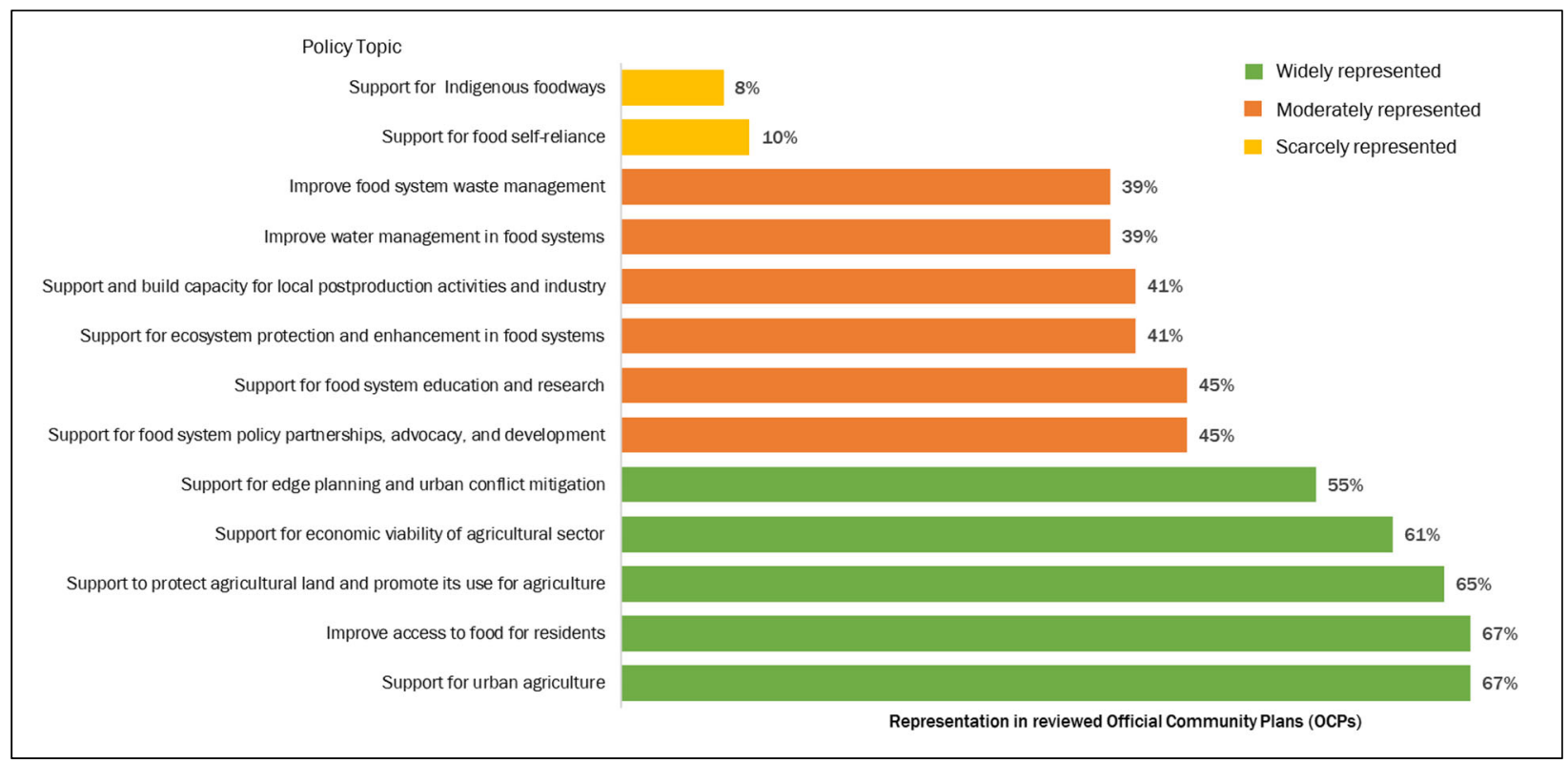


O nly two topics were identified as scarcely represented: (1) policies in support of food selfreliance (10\%), and (2) policies supporting Indigenous foodways (8\%).

F oundational E lements of Regional F ood Systems Policy in BC OCPS and Comparison among Rural and U rban Communities

The foundational regional food system element, protecting agricultural land and promoting its use for farming, was the third most widely represented topic across all municipalities (Figure 2). This topic was evenly represented among both urban and rural municipalities. While the use of most agricultural land in BC is regulated through the Agricultural Land Reserve (ALR)--a provincial land use zone--local governments do play a critical role in implementing and enforcing ALR land use regulations within their jurisdictions. This responsibility is widely recognized, considering that $65 \%$ of reviewed municipalities include policy statements in their OCP to protect agricultural land and/ or promote its use for farming. It is somewhat surprising, however, that the rate of representation for this fundamentally important foundational element is not more ubiquitous.

The subtopics for this policy (Appendix A) suggest that policy primarily targets farmland protection (e.g., maintaining stable ALR boundaries and/ or parcel sizes conducive to farming, supporting urban containment boundaries, regulating residential development), but not the promotion of its use for agriculture (e.g., supporting land access for farmers). The underutilization of farmland in the ALR is an area of increasing concern in BC. Particularly in peri-urban areas, where agricultural land is highly fragmented, land use competition is intense, and valuation precludes economically viable agriculture (Mullinix et al., 2013; Sussmann, D orward, Polasub, Mullinix, \& Mansfield, 2016). Exacerbating this is the erroneous perception that low input, small lot agriculture is generally a niche endeavor that cannot and/ or will not be an important part of our food system (Holt-Giménez, 2017). In these regions, the use of farmland for residential development is particularly prevalent (Cooper, 2017; Metro Vancouver, 2016; Tomlinson, 2016)

Figure 3. Proportion of Urban $(n=22)$ and Rural $(n=27)$ M unicipalities with Given Food System Policy Topic Represented in their Official Community Plan (OCP).

Population density of rural municipalities $<400$ people $/ \mathrm{km}^{2}$

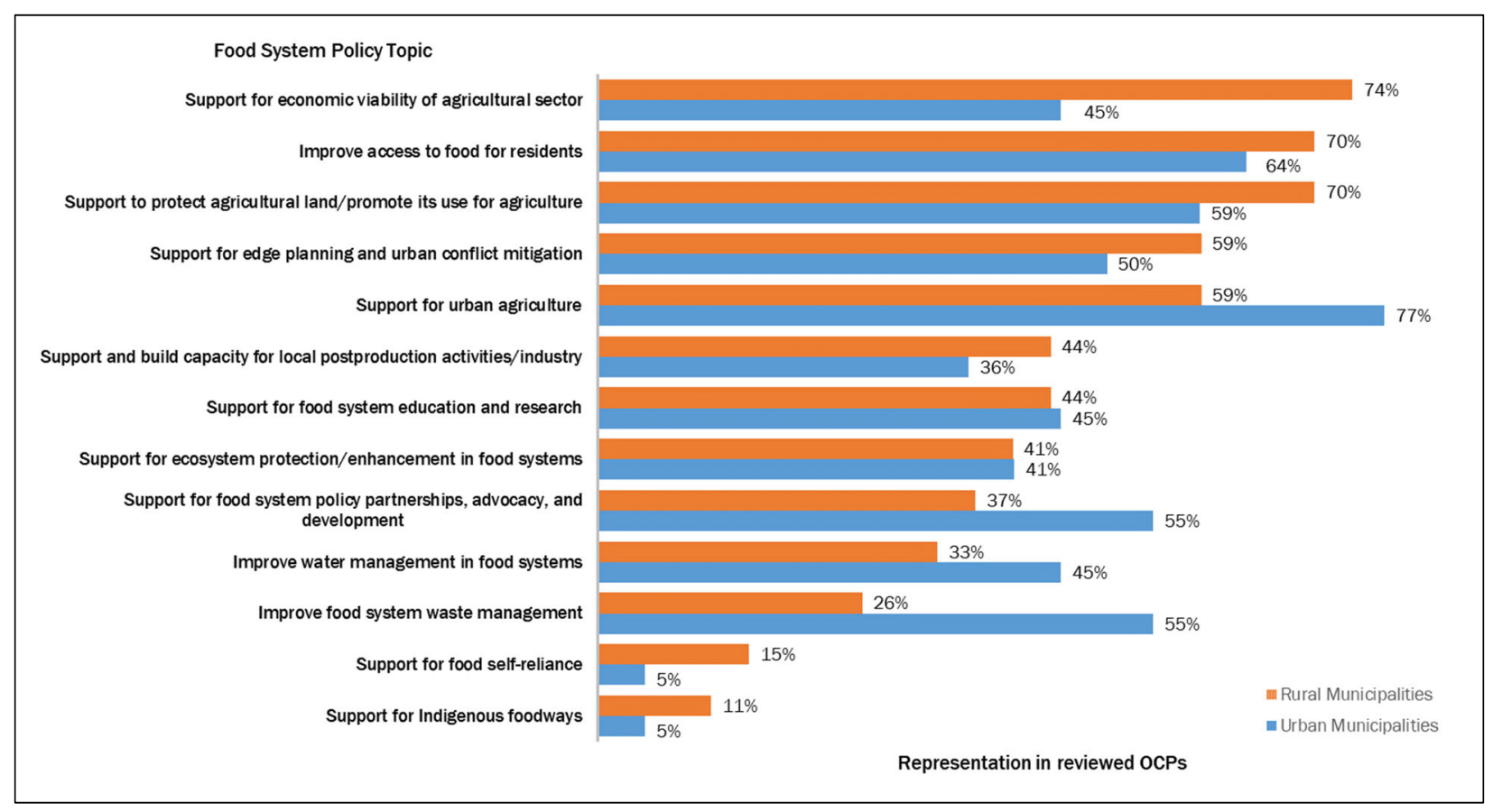


given that the current property tax regime provides considerable financial benefit to landowners who wish to use land in the ALR for residential purposes (Metro Vancouver, 2016; Tatebe, Robert, Liu, dela Rosa, Wirsching, \& Mullinix, 2018). A Metro Vancouver land use inventory report revealed that only $50 \%$ of the region's ALR land base is used for farming, and almost half of the nonfarm land uses are residential. O ther common nonfarm uses of ALR land include golf courses, parks, and natural vegetation (BC MoA, 2014). While addressing this issue requires reform at the provincial level, a recent report identifies that local governments can play a role by both advocating for change, and by improving communication of land use activities to the provincial land assessment authority (Metro Vancouver, 2016). We note that neither of these actions was represented in the OCPs reviewed in this study, and developing the role of local governments in promoting the use of agricultural land for agricultural purposes is an area of needed attention.

Additionally, we note that the regulation of fill (soil) deposition on agricultural land is another dimension of farmland protection that is largely absent. This is an issue of increasing concern (Nagel, 2015) due to the potential for agricultural land degradation resulting from poor fill quality. The Agricultural Land Commission has reported an increase in both the number of applications and the volume of fill. Where previous requests were typically $3.3 \mathrm{ft}(1 \mathrm{~m})$ in depth, some current requests exceed $23 \mathrm{ft}(7 \mathrm{~m})$ of fill, which is generally characterized as poor quality for agricultural purposes (K. Glavas, personal communication, August 2017). This is especially prevalent in the Lower Mainland, where the excavated materials generated from rampant development in adjacent urban centers must be accommodated, and financial gain for property owners from tipping (soil deposition) fees are substantial. Fill depositions, both authorized and unauthorized, are also increasing in other areas of the province experiencing population growth and proliferation of other economic interests (K. Glavas, personal communication, August 2017). Additionally, unauthorized fill sites compose almost $45 \%$ of the ALC's Compliance and
Enforcement files (ALC, 2017). While it is recognized that the regulation of fill deposits on agricultural land can be addressed in planning documents outside of OCPs, there is an opportunity to increase local government involvement in mitigating this serious issue by recognizing it as an important component of OCP policies protecting agricultural land.

Policies supporting economic development of the agricultural sector were the fourth most widely represented topic across municipalities; however, this topic was represented at notably different levels between urban and rural municipalities. This foundational regional food system element was addressed in $74 \%$ of rural, but only $45 \%$ of urban municipalities. Widespread support among rural municipalities likely reflects the relatively high proportion of residents in rural areas whose livelihoods are linked to the agricultural sector and a sense of potential influence. Conversely, for urban municipalities, the relative lack of such policy could be indicative of a disconnect between urbanites and rural food producing areas. If urban municipalities wish to support regional food systems, they must recognize their connection to, and role in, supporting the economic vitality of the agricultural hinterlands that could be a significant source of their residents' food. For example, dedicating the substantial purchasing power of public institutions (e.g., schools and hospitals) in urban areas toward supporting the regional agricultural sector has been identified an important avenue for scaling up demand for, and access to, local foods while supporting rural economies (Benson \& Fleury, 2017; Conner et al., 2011; Friedmann, 2007; Klein, 2015). Despite this, policies supporting local procurement (in institutions) were present in relatively few O CPs (12\%), and therefore represent an area of future policy focus for enabling regional food systems.

Support for local postproduction infrastructure and activities was moderately represented and is recommended as an area of future policy progress for the development of regional food systems. The topic was present in only $41 \%$ of OCPs, with similar representation in urban and rural municipalities (36\% and 44\%, respectively). Postproduction capacity is key to actualizing a viable regional 
food system and realizing the associated economic benefits (Mullinix et al., 2016). Processing capacity can both facilitate the off-season consumption of regional agricultural products and increase their market value. Equally important for regional food systems are storage and distribution channels targeted for regional markets, which can allow regionally produced food to reach regional consumers. However, the centralization of food processing across Canada has hindered the ability of producers (particularly small-scale) to process products for local markets (FSC, 2011). The diminution of BC's local processing capacity has been attributed to both consolidation and centralization in the agri-food sector (Rice, 2014), and to disabling regulatory environments. For example, in 2004 BC imposed new "meat inspection regulations that essentially eliminated small-scale abattoirs" in the province (Miewald, Ostry, \& Hodgson, 2013, p. 93).

The policy topic addressing improved food access was present in $67 \%$ of reviewed OCPs and was widely represented in both urban and rural municipalities. Food access included availability, quality, proximity to markets, affordability, and utilization (Chase \& G rubinger, 2014). While food access was found to be a priority policy area for BC municipalities, the topic of Indigenous foodways was represented in only $8 \%$ of OCPs. Given that Indigenous peoples and communities experience disproportionately high levels of poverty and food insecurity relative to the general population, and that Indigenous Nations are integral to BC culture and identity (De Schutter, 2012), this topic represents an area of much-needed policy development. Elevated food insecurity among Indigenous communities is an artifact of long-standing political, social, and economic marginalization (read: colonialism). This includes, but is not limited to, a disproportionate impact of resource extraction on Indigenous food lands, denying Indigenous people access to their traditional fishing, hunting and gathering sites, confining Indigenous peoples to increasingly smaller areas, and active efforts to erode Indigenous knowledge and culture (D aschuk, 2013; Truth and Reconciliation Commission of Canada [TRC], 2015). While it is recognized that strengthening Indigenous foodways is inextricably linked to larger shifts in federal and provincial policy related to Indigenous rights and reconciliation efforts (Coté, 2010; Manuel \& D errickson, 2015), local governments can and should assume an active role. In their local government capacitybuilding work, Clark et al. (2017) reflect on how the active engagement of those affected by food system inequalities is critical to the development of policies that support equitable food systems. Prioritizing biodiversity conservation in land use planning, incorporating Indigenous food sovereignty into community planning, and increasing institutional support for Indigenous food programs have been identified as avenues for local governments to strengthen Indigenous food systems (Morrison, 2008). However, actualizing these policy directives will require that the implicated communities be actively and directly engaged in their development. Additionally, policymakers must be ready to challenge dominant narratives, such as the prevailing "highly mechanistic, linear food production, distribution, and consumption model applied in the industrialized food system" (Morrison, 2008, p. 5.) that can reinforce food system inequalities. Examples of current OCP policies addressing Indigenous food systems include maintaining access to natural and traditional food lands, undertaking inventories of municipal lands to better identify traditional food resources, and promoting education initiatives surrounding Indigenous foodways (City of Terrace, 2011, p. 11-12; City of Victoria, 2012, p. 121). These can serve as a starting point for supporting Indigenous foodways, which, at present, represents a nascent area of municipal policy. D espite its low representation among $\mathrm{BC} O \mathrm{OCPs}$, this is a critically important area for achieving more equitable and socially just regional food systems, as the imposition of any food system upon Indigenous communities can be seen as an avenue to further marginalization (Mullinix, 2016).

Improving food system waste management was also reflected in a relatively few number of O CPs (39\%), and primarily among urban municipalities. While food waste occurs at all stages of the supply chain, in industrialized countries like Canada, approximately one-third to one-half of food waste occurs at the consumer 
and/ or retail stage of the supply chain, generating significant environmental and economic costs (FAO , 2011; G ooch, Felfel, \& Marenick, 2010). In Metro Vancouver, food waste composed over $20 \%$ of municipal waste (Tetra Tech, 2016). Municipal efforts to prevent and recover food waste, including collection programs, education initiatives, and food recovery initiatives are therefore suggested as an area of future policy development.

Policy-level support for environmental stewardship in food system was moderately represented (41\%), with similar representation for both urban and rural municipalities. Given the significant impacts of food systems on ecological systems--including water pollution, soil degradation, loss of habitat and biodiversity, greenhouse gas emissions, etc.--and the associated societal and health consequences, we suggest this, too, as a requisite area of policy attention.

Policy supporting urban agriculture was the second most represented topic across all municipalities and density groups. This result reflects observations in food system policy research and practice that, to date, urban agriculture is among the most targeted aspects of municipal food planning (City of Victoria, n.d.; Mansfield \& Mendes, 2013). This production focus is not unique to $B C$, but reflective of a dominant planning approach that has been critiqued for ignoring the interconnected elements that compose a functioning food system, such as processing infrastructure, distribution and storage networks, and waste reclamation programs (Raja, Picard, Baek, \& D elgado, 2014). Furthermore, some OCPs include urban agriculture as part of food security strategies (City of North Vancouver, 2014; City of Victoria, 2012). While urban agriculture has the potential to achieve multiple social and urban planning goals, (e.g., food literacy, urban greening), the framing of urban agriculture as a food security strategy has been critiqued based on its limited potential to satisfy the caloric requirements of urban populations (MacRae, Gallant, Patel, Michalak, Bunch \& Schaffner, 2010; Pynn, 2015; Badami \& Ramankutty, 2015.) Furthermore, a multiyear investigation of policy interventions to reduce Canadian household food insecurity found gardening to be unrelated to the occurrence of food insecurity (Huisken, O rr, \& Tarasuk, 2017). Lastly, the dominance of urban agriculture policy may simply be a reflection of the newness of food system planning in $\mathrm{BC}$ and a lack of more sophisticated local-regional food system thinking. As such, we suggest that local governments emphasize expanding the scope of food system planning beyond their own municipal boundaries and recognize the regional context of a food system and its many interconnected attributes. If robust regional food systems are to be, municipalitiesboth urban and rural - must act in concert via a common vision with interactive and mutualistic policy.

\section{Conclusions}

Per our assumptions and framework, this study revealed the thematic range and prevalence of food system policy in BC Official Community Plans. At present, food access and urban agriculture are the primary foci of municipal food policy in OCPs. We propose that support for traditional foodways and access to culturally appropriate food for Indigenous peoples should receive substantially increased attention among food access policies. Critical to achieving this is the active inclusion of Indigenous communities in the policy development process as well as the willingness of governments to challenge longstanding narratives that reinforce food system inequalities. We identified postproduction capacity for regional markets, food waste management, and fostering environmental stewardship as lacking regional food system policies. While policies to protect agricultural land and promote its use for farming were widespread, the regulation of fill (soil) deposition is an area of need policy attention. Finally, we observed a number of discrepancies between rural and urban policy priorities. These discrepancies, particularly concerning the economic development of the agricultural sector, offer a basis for future study into how we might advance regional food system planning that recognizes important links between rural and urban areas. Local procurement initiatives within public institutions have been identified as one avenue in which links can be established between urban areas and rural areas. Coordination across municipal 
boundaries, in our view, will require municipalities to expand food system policy efforts beyond their current urban agriculture focus, which has been critiqued as having a limited capacity to address a number of pressing food system concerns.

The complex and interconnected nature of our food system allows actions within one component to impact other food system components. This presents a particular challenge for segregating food system policy into singular groupings. For example, support for direct marketing (such as farmers markets) can improve food access for residents while simultaneously providing diverse economic opportunities to improve the economic viability of the agricultural sector. For the purpose of completing this analysis, policy was coded according to the themes directly communicated in the written policy. While this perspective allows for food policies to be coded and assessed, it limits the assessment of the cross-cutting impacts of food system policy. Evaluating the strength of $\mathrm{BC}$ food system policies and plans is an additional area of future study that may be completed via plan quality assessments (Evans-Cowley, 2011; Hodgson, 2012; Youmans, 2014). The framework we developed and applied can serve as a tool in other jurisdictions to gain insight into local government priorities concerning regional food system policy, monitor their evolution, and identify areas for future policy development.

\section{References}

Agricultural Land Commission [ALC]. (2002). Agricultural Land Reserve Use, Subdivision and Procedure Regulation. Canada. Retrieved from http:// www.bclaws.ca/ civix/ document/id/ complete/ statreg/ 1712002

ALC. (2017). Provincial A gricultural L and Commission A nnual Report 2016-2017. Retrieved from https:// www.alc.gov.bc.ca/ alc/ content/ library/ commission-reports

American Planning Association [APA]. (2007). Policy guide on Community and Regional Food Planning. Retrieved from https:/ / www.planning.org/ policy/ guides/ adopted/ food.htm

Badami, M. G., \& Ramankutty, N. (2015). Urban agriculture and food security: A critique based on an assessment of urban land constraints. G lobal F ood Security, 4(Supplement C), 8-15. https:/ doi.org/ 10.1016/ j.gfs.2014.10.003

Bell, A. (2010). Food insecurity in the land of plenty: The Windermere Valley paradox. In A. Blay-Palmer (Ed.), Imagining sustainable food systems: Theory and practice (pp. 201-222). New York: Routledge. Retrieved from https:/ / www.taylorfrancis.com/ books/ e/ 9781317118633/ chapters/ 10.4324\%2F9781315587905-11

Benson, M., \& Fleury, D. (2017). Institutions: An emerging market for local and regional foods. In A. D umont, D. D avis, J. Wascalus, T. C. Wilson, J. Barham, \& D. Tropp (Eds.), H arvesting opportunity: The power of regional food system investments to transform communities (pp. 189-207). Washington, D.C.: Federal Reserve Bank of St. Louis and the Board of Governors of the Federal Reserve System.

Born, B., \& Purcell, M. (2006). Avoiding the local trap. Journal of Planning E ducation and Research, 26(2), 195-207. https:// doi.org/ 10.1177/ 0739456X06291389

British Columbia D evelopment Regions. (n.d.). Census boundaries. Retrieved from http:// www2.gov.bc.ca/ gov/ content/ data/ geographic-data-services/ land-use/ administrative-boundaries/ censusboundaries

British Columbia Ministry of Agriculture [BC MoA]. (2014). Metro Vancouver land use inventory report summer 2010 \& 2011. Retrieved from https:/ / www2.gov.bc.ca/ gov/ content/ industry/ agriculture-seafood/ agricultural-land-andenvironment/ strengthening-farming/ planning-for-agriculture/ agricultural-land-use-inventories/ south-coast

BC MoA. (2015a). G uide for bylaw development in farming areas. Retrieved from http:// www2.gov.bc.ca/gov/ content/ industry/ agriculture-seafood/ agricultural-land-andenvironment/ strengthening-farming/ local-government-bylaw-standards-and-farm-bylaws

BC MoA. (2015b). G uide to edge planning. Retrieved from http:/ / www2.gov.bc.ca/ gov/ content/ industry/ agricultureseafood/ agricultural-land-and-environment/ strengthening-farming/ edge-planning

Capital Regional D istrict [CRD ]. (2016). Setting our table, C apital R egional D istrict food \& agriaulture strategy D RA FT. Retrieved from http:/ / www.crd.bc.ca/ project/ food-agriculture

Chase, L. \& G rubinger, V. (2014). F ood, farms, and community: E x ploring food systems. (p. 138-164). Lebanon: University of New Hampshire Press. 
Journal of Agriculture, Food Systems, and Community Development

ISSN: 2152-0801 online

https:/ / www.foodsystemsjournal.org

City of North Vancouver. (2014). City of North Vancouver Community Plan Bylaw No. 8400. Retrieved from http:// www.cnv.org/ your-government/ official-community-plan

City of Richmond. (2016). City of Richmond Food Charter. Retrieved from https:// www.richmondfoodsecurity.org/ richmond-food-charter/

City of Terrace. (2011). City of Terrace Official Community Plan Schedule A. Retrieved from http:/ / www.terrace.ca/ city-hall/ bylaws

City of Vancouver. (2013). V anoouver F ood Strategy. Retrieved from http:/ / vancouver.ca/ people-programs/ vancouversfood-strategy.aspx

City of Victoria. (n.d.). G rowing in the City Retrieved from https:/ / www.victoria.ca/ EN/ main/ residents/ parks/ growingin-the-city.html

City of Victoria. (2012). City of Victoria O fficial Community Plan. Retrieved from http:/ / www.victoria.ca/ EN/ main/ residents/ community-planning/ official-community-plan.html

Clapp, J. (2012). F ood. Cambridge, UK: Polity Press.

Clark, J., Freedgood, J., Irish, A., Hodgson, K., \& Raja, S. (2017). Fail to include, plan to exclude: Reflections on local governments' readiness for building equitable community food systems. Built E nvironment, 43(3), 315-327. https:// doi.org/ 10.2148/ benv.43.3.315

Cleveland, D . A., Müller, N. M., Tranovich, A. C., Mazaroli, D. N., \& Hinson, K. (2014). Local food hubs for alternative food systems: A case study from Santa Barbara County, California. Journal of Rural Studies, 35(Supplement C), 26-36. https:// doi.org/ 10.1016/j.jrurstud.2014.03.008

Conner, D. S., Nowak, A., Berkenkamp, J., Feenstra, G. W., Van Soelen Kim, J., Liquori, T., \& Hamm, M. W. (2011). Value chains for sustainable procurement in large school districts: Fostering partnerships. Journal of A griaulture, F ood Systems, and Community D evelopment, 1(4), 55-68. https:/ / doi.org/ 10.5304/ jafscd.2011.014.005

Cooper, S. (2017, May 26). Speculators target B.C. farmland after foreign buyer tax introduced for residences. V ancouver Sun. Retrieved from http:/ / vancouversun.com/ news/ local-news/ farmland

Corporation of D elta. (1979). D elta Z oning Bylaw N 0. 2750. Retrieved from https:/ / delta.civicweb.net/ filepro/ documents/ 38103

Coté, C. (2010). Spirits of our W haling A noestors: R evitalizing Makah \& N uu-chah-nulth T raditions. Seattle: University of Washington.

Cowichan Green Community. (2009). Cowichan Food Charter. Retrieved from https:/ / cowichangreencommunity.org/ resource/ cowichan-food-charter/

Daschuk, J. (2013). Clearing the plains: D isease, politics of starvation, and the loss of aboriginal life. Regina, Saskatchewan, Canada: University of Regina Press.

De Schutter, O. (2012). Report of the Special Rapporteur on the Right to Food, Olivier de Schutter: A ddendum, Mission to C anada, 24 D ecember 2012, A/ HRC/ 22/ 50/ Add.1. UN Human Rights Council. Retrieved from http:// www.refworld.org/ docid/511cb0422.html

Desjardins, E. (2010). The urban food desert: Spatial inequality or opportunity for change? In A. Blay-Palmer (Ed.), Imagining sustainable food systems (pp. 87-115). London: Routledge.

Evans-Cowley, J. S. (2011). Evaluating food systems in comprehensive planning: Is the Mississippi Gulf Coast planning for food? Journal of A griculture, F ood Systems, and C ommunity D evelopment, 2(1), 105-126. https:// doi.org/ 10.5304/ jafscd.2011.021.009

Feenstra, G . (2002). Creating space for sustainable food systems: Lessons from the field. A griculture and $\mathrm{H}$ uman V alues, 19(2), 99-106. Retrieved from https:/ / doi.org/ 10.1023/ A:1016095421310

Finnigan, P. (2017). A food policy for Canada, report of the Standing C ommittee on A griculture and A gri-F ood. House of Commons Canada. Retrieved from https:/ / www.ourcommons.ca/ D ocumentViewer/ en/ 42-1/ AGRI/ report-10/

Food and Agriculture Organization of the United Nations [FAO ]. (2011). G lobal food losses and food waste- Ex tent, causes and prevention. Retrieved from http:/ / www.fao.org/ docrep/ 014/ mb060e/ mb060e00.htm

FAO . (2017). The state of food searity and nutrition in the world 2017. Retrieved from http:/ / www.fao.org/ state-of-foodsecurity-nutrition/ en/

Food Secure Canada [FSC]. (2011). D iscussion paper 4: A griculture, infrastructure and livelihoods. People's Food Policy Project. Retrieved from https:/ / foodsecurecanada.org/ resources-news/ newsletters/ discussion-papers-peoples-food-policy 
FSC. (2015). Resetting the table: A people's food policy for C anada. (2nd ed.). Retrieved from https:/ / foodsecurecanada.org/ people-food-policy

Fridman, J., \& Lenters, L. (2013). Kitchen as food hub: Adaptive food systems governance in the City of Toronto. L ocal E nvironment, 18(5), 543-556. https:/ / doi.org/ 10.1080/ 13549839.2013.788487

Friedmann, H. (2007). Scaling up: Bringing public institutions and food service corporations into the project for a local, sustainable food system in O ntario. A griculture and $\mathrm{H}$ uman V alues, 24(3), 389-398. https:/ / doi.org/ 10.1007/ s10460006-9040-2

Gooch, M., Felfel, A., \& Marenick, N. (2010). Food waste in Canada. Retrieved from http:// vcm-international.com/ wpcontent/ uploads/ 2013/ 04/ Food-Waste-in-Canada-112410.pdf

Government of British Columbia. (2015). Local G overnment Act. Part 14, Division 4 - Official Community Plans. Retrieved from http:/ / www.bclaws.ca/ civix/ document/ id/ complete/ statreg/r15001 14\#division_d0e43604

Gwin, L., \& McCann, N. (2017). Use it or lose it: Local food, regional processing and the perils of unused capacity. In A. D umont, D. Davis, J. Wascalus, T. C. Wilson, J. Barham, \& D. Tropp (Eds.), H arvesting opportunity: The power of regional food system investments to transform communities (pp. 189-207). Washington, D .C.: Federal Reserve Bank of St. Louis and the Board of G overnors of the Federal Reserve System. Retrieved from https:// www.stlouisfed.org/ / media/ Files/ PD Fs/ Community-D evelopment/ HarvestingOpportunity/ Harvesting_Opportunity.pdf?la=en

Harris, G., Nixon, D., Newman, L., \& Mullinix, K. (2016). D elineating the Southwest British Columbia bioregion for food system design and planning: A practical approach. Journal of A griculture, Food Systems, and C ommunity D evelopment, 6(4), 1-16. https:/ / doi.org/ 10.5304/ jafscd.2016.064.010

Heffernan, W. (2006). Understanding what's happening in our food and farming systems. In K. Mullinix (Ed.), The nex t agricultural revolution: Revitalizing family-based agriculture and rural ommunities (pp. 11-21). Y akima, WA: G ood Fruit Grower.

Hodgson, K. (2012). Planning for food acess and community-based food systems: A national scan and evaluation on local comprehensive and sustainability plans. American Planning Association. Retrieved from https:/ / www.planning.org/ research/ foodaccess/

Holt-G iménez, E. (2017). A foodie's guide to capitalism. New Y ork: Monthly Review Press \& Food First Books.

Huisken, A., O rr, S. K., \& Tarasuk, V. (2017). Adults' food skills and use of gardens are not associated with household food insecurity in Canada. Canadian Journal of Public H ealth, 107(6), e526-e532. https:// doi.org/ 10.17269/ cjph.107.5692

Institute for Sustainable Food Systems [ISFS]. (2017). BC Food System Policy D atabase. Retrieved from https:// www.kpu.ca/ isfs/ foodpolicydatabase

International Panel of Experts on Sustainable Food Systems [IPES Food]. (2017) Too big to feed: E x ploring the impads of mega-mergers, concentration, concentration of power in the agri-food sector. Retrieved from http:/ / www.ipesfood.org/ publications

Jablonski, B. B. R., Hendrickson, M., Vogel, S., \& Schmit, T. (2017). Local and regional food systems driving rural economic development. In A. D umont, D. D avis, J. Wascalus, T. C. Wilson, J. Barham, \& D. Tropp (Eds.), $\mathrm{H}$ arvesting opportunity: The power of regional food system investments to transform communities (pp. 189-207). Washington, D .C.: Federal Reserve Bank of St. Louis and the Board of G overnors of the Federal Reserve System. Retrieved from https:// www.stlouisfed.org/ / media/ Files/ PD Fs/ Community-D evelopment/ HarvestingOpportunity/ Harvesting_O pportunity.pdf?la=en

Klassen, S. E., \& Wittman, H. (2017). Place-based food systems: "Re-valuing local” and fostering socio-ecological sustainability. In J. D uncan \& M. Bailey (Eds.), Sustainable food futures: Multidisciplinary solutions. London and New York: Routledge.

Klein, K. (2015). Values-based food procurement in hospitals: The role of health care group purchasing organizations. A griculture and H uman V alues, 32(4), 635-648. https:/ / doi.org/ 10.1007/ s10460-015-9586-y

MacRae, R. (1999). Policy Failure in the Canadian Food System. In M. Koc, L. Mougeot, \& J. Welsh (Eds.), F or H ungerProof Cities: Sustainable U rban F ood Systems (pp. 182-194). Ottawa: International D evelopment Research Centre. Retrieved from https:/ / www.idrc.ca/ en/ book/ hunger-proof-cities-sustainable-urban-food-systems 
Journal of Agriculture, Food Systems, and Community D evelopment

ISSN: 2152-0801 online

https:/ / www.foodsystemsjournal.org

MacRae, R., \& D onahue, K. (2013). M unicipal food policy entrepreneurs: A preliminary analysis of how Canadian cities and regional distrids are involved in food system change. O ttawa: Canadian Agri-Food Policy Institute. Retrieved from Canadian Electronic Library/ desLibris.

MacRae, R., Gallant, E., Patel, S., Michalak, M., Bunch, M., \& Schaffner, S. (2010). Could Toronto provide 10\% of its fresh vegetable requirements from within its own boundaries? Matching consumption requirements with growing spaces. Journal of A griculture, Food Systems, and Community D evelopment, 1(2), 105-127. https:/ / doi.org/ 10.5304/ jafscd.2010.012.008

Mansfield, B., \& Mendes, W. (2013). Municipal food strategies and integrated approaches to urban agriculture: Exploring three cases from the global north. International Planning Studies, 18(1), 37-60. https:/ / doi.org/ 10.1080/ 13563475.2013.750942

Manuel, A., \& D errickson, G. C. R. (2015). U nsettling Canada: A national wakeup call. Toronto: Between the Lines.

Metro Vancouver. (2011). Regional food system strategy. Retrieved from http:// www.metrovancouver.org/ services/ regionalplanning/ agriculture/ rfs-strategy/ Pages/ about-the-strategy.aspx

Metro Vancouver. (2016). E noouraging agricultural production through farm property tax reform in $\mathrm{M}$ etro $\mathrm{V}$ anouver. Retrieved from http:/ / www.metrovancouver.org/ Search/ Pages/ results.aspx?k=farm\%20property\%20tax

Miewald, C., O stry, A., \& Hodgson, S. (2013). Food safety at the small scale: The case of meat inspection regulations in British Columbia's rural and remote communities. Journal of Rural Studies, 32(Supplement C), 93-102. https:// doi.org/ 10.1016/j.jrurstud.2013.04.010

Mills, R. J. A. (2011). The role of municipalities in planning for a sustainable agri-food system: A case study of Surrey, BC (Masters thesis). University of British Columbia, Vancouver. https:/ / dx.doi.org/ 10.14288/ 1.0102527

Morgan, K. (2009). Feeding the city: The challenge of urban food planning. International Planning Studies, 14(4), 341-348. https:/ / doi.org/ 10.1080/ 13563471003642852

Morland, K. B. (Ed.). (2015). L ocal food environments: Food acoess in A merica. Boca Raton, FL: CRC.

Morone, P., Papendiek, F., \& Tartiu, V. E. (Eds.). (2017). F ood waste reduction and valorisation: Sustainability assessment and policy analysis. Springer International Publishing. https:/ / doi.org/ 10.1007/ 978-3-319-50088-1

Morrison, D . (2008). B.C. Food Systems Network: Working group on Indigenous food sovereignty final activity report. Retrieved from https:// www.indigenousfoodsystems.org/ sites/default/ files/ resources/WGIFS_Final_Report_March_08.pdf

Mullinix, K. (2016). G uest editorial: Working with indigenous peoples to foster sustainable food systems. Journal of A griculture, F ood Systems, and Community D evelopment, 5(4), 3-6. https:// doi.org/ 10.5304/ jafscd.2015.054.008

Mullinix, K., D orward, C., Shutzbank, M., Krishnan, P., Ageson, K., \& Fallick, A. (2013). Beyond protection: D elineating the economic and food production potential of underutilized, small-parcel farmland in metropolitan Surrey, British Columbia. Journal of A griculture, Food Sytems, and C ommunity D evelopment, 4(1), 33-50. https:// doi.org/ 10.5304/ jafscd.2013.041.005

Mullinix, K., D orward, C., Sussmann, C., Polasub, W., Smukler, S, Chiu, C.,... Kissinger, M. (2016). The Future of 0 ur F ood System: Report on the Southwest BC Bioregion F ood System D esign Project. Institute for Sustainable Food Systems. Richmond, British Columbia: Kwantlen Polytechnic University. https:// doi.org/ 10.13140/ RG .2.2.22261.37607

Nagel, J. (2015, May 31). Metro cities target illegal fill dumping on farmland. BurnabyN ow. Retrieved from http:/ / www.burnabynow.com/ news/ metro-cities-target-illegal-fill-dumping-on-farmland-1.1950589

Nestle, M. (2002). F ood politics: H ow the food industry influenœes nutrition and health. Berkeley: University of California Press.

Neuner, K., Kelly, S., \& Raja, S. (2011). Planning to eat? Innovative local government plans and policies to build healthy food systems in the U nited Staes. Food Systems Planning and Healthy Communities Lab. Buffalo: University at Buffalo, The State University of New Y ork. Retrieved from http:/ / cccfoodpolicy.org/ document/ planning-eat-innovative-localgovernment-plans-and-policies-build-healthy-food-systems-unit

North Shore Table Matters. (2013). North Shore Community Food Charter. Retrieved from http:/ / www.tablematters.ca/ tm-projects/ north-shore-food-charter/

Patel, R. (2008). Stuffed and starved: M ark ets, power and the hidden battle for the world's food system (1st Canadian ed.). Toronto: HarperCollins.

Pothukuchi, K., \& Kaufman, J. L. (2000). The food system: A stranger to the planning field. Journal of the A merican Planning A ssociation, 66 (2), 113-124. https:// doi.org/ 10.1080/ 01944360008976093 
Pynn, L. (2015, D ecember 2). Market gardens not the answer to B.C.'s food challenges. V ancouver Sun. Retrieved from http:/ / www.vancouversun.com/ life/ market+gardens+answer+food+challenges/11558267/ story.html

Raja, S., Picand, D ., Baek, S., \& D elgado, C. (2014). Rustbelt radicalism: A decade of food systems planning practice in Buffalo, New York. Journal of A griculture, Food Systems, and Community D evelopment, 4(4), 1-17. http:// doi.org/ 10.5304/ jafscd.2014.044.015

Rice, G . (2014). The L ower M ainland food system: The role of fruit and vegetable processing (Unpublished master's dissertation). Simon Fraser University, Vancouver, British Columbia. Retrieved from http:/ / summit.sfu.ca/ item/ 13904

Schiff, R. (2007). Food policy councils: A n ex amination of organisational structure, process, and contribution to alternative food movements (D octoral dissertaton). Murdoch University, Perth, Australia. Retrieved from http:/ / researchrepository.murdoch.edu.au/ id/ eprint/ 293/

Selkirk D esign and Planning, \& Ross, H. (2014). Revelstok e food seaurity strategy. Retrieved from http:/ / www.cityofrevelstoke.com/ 437/ Key-Reports-D ocuments

Statistics Canada. (n.d.). Self-contained labour areas: A proposed delineation and classification by degree of rurality: $\mathrm{D}$ ata and D efinitions. Retrieved from http:// www.statcan.gc.ca/ pub/21-006-x/ 2008008/ section/ s2-eng.htm

Statistics Canada. (2011). Census of population. Retrieved from http:// www12.statcan.gc.ca/ censusrecensement/2011/ dp-pd/prof/ index.cfm?Lang=E

Statistics Canada. (2015). Table 11-10-0125-01 D etailed food spending, Canada, regions and provinces. CANSIM (database). Retrieved from http:/ / www5.statcan.gc.ca/ cansim/ a26?lang=eng\&id=2030028

Statistics Canada. (2016). Census profile household dwelling characteristics. Retrieved from http:// www12.statcan.gc.ca/ census-recensement/ 2016/ dp$\mathrm{pd} / \mathrm{prof} /$ details $/$ Page.cfm?Lang=E\&Geo1=PR\&Code1=59\&G eo2=PR\&Code2=01\&D ata=Count\&SearchText $=$ British\%20Columbia\&SearchType=Begins\&SearchPR=01\&B1=All\&G eoLevel=PR\&G eoCode $=59$

Sussmann, C., D orward, C., Polasub, W., Mullinix, K., \& Mansfield, B. (2016). H ome on the range: Cost pressures and the priœe of farmland in Metro $\mathrm{V}$ anouver. Vancouver: Vancity. Retrieved from https:/ / www.vancity.com/ SharedContent/ documents/ pdfs/ News/ Vancity-Report-Cost-Pressures-and-the-Priceof-Farmland-in-Metro-Vancouver-2016.pdf

Sussmann, C., \& Feeney, C. (2015). L ocal food futures for British Columbia, Findings from regional dialogues. Retrieved from http:// www.kpu.ca/ isfs/ publications

Tatebe, K., Robert, N., Liu, R., dela Rosa, A., Wirsching, E., \& Mullinix, K. (2018). Protection is N ot E nough: Policy Precedents to Increase the A gricultural U se of BC's F armland. Institute for Sustainable Food Systems. Richmond, British Columbia: Kwantlen Polytechnic University. Retrieved from http:// www.kpu.ca/ isfs/ agriculturalland-use-in-the-alr

Tetra Tech EBA Inc. (2016). 2015 W aste Composition M onitoring Program. Retrieved from http:// www.metrovancouver.org/ services/ solidwaste/ SolidWastePublications/2015 Waste Composition Report.pdf

Tomlinson, K. (2016, November 18). O n B.C.'s farmland, mega-mansions and speculators reap the rewards of lucrative tax breaks. The G lobe and M ail. Retrieved from https:/ / beta.theglobeandmail.com/ news/ investigations/ farmlandand-real-estate-in-british-columbia/ article32923810/

Township of Langley. (1987). Township of Langley zoning bylaw No. 2500. Retrieved from https:/ / www.tol.ca/ at-yourservice/ bylaw-enforcement/ bylaws/

Truth and Reconciliation Commission of Canada (TRC). (2015). H onouring the truth, reconciling for the future. Retrieved from http:// www.trc.ca/ websites/ trcinstitution/ index.php?p=890

Warshall, P., Briscoe, M., Ingram, M., Buchman, S., Nabhan, G., Badgley, C., \& Tucker, K. R. (2002). Ecological impacts. In A. Kimbrell (Ed.), T he F atal H arvest Reader (pp. 167-208). Sausalito, CA: Foundation for D eep Ecology in collaboration with Island Press.

World Health Organization [WHO ]. (2017). O besity and overweight fact sheet. Retrieved from http:/ / www.who.int/ mediacentre/ factsheets/ fs311/ en/

Youmans, J. (2014). A re BC municipalities planning for food?: A n evaluation of official community plans (Unpublished masters dissertation). University of British Columbia, Vancouver. https:/ / doi.org/ 10.14288/ 1.0075847 


\section{Appendix A. Complete List of Topics and Subtopics Used to Thematically Categorize Food System Policy in Official Community Plans}

Policy Topics and Subtopics

1. Support and build capacity for local postproduction activities/industry

a. Support and build capacity for local food distribution

b. Support and build capacity for local food processing

c. Support and build capacity for local food storage

2. Improve access to food for residents

a. Support access to affordable/nutritious food

b. Support access to food retail locations (not direct-marketing)

c. Support for community kitchens

d. Support for direct marketing

e. Support for emergency food sources

f. Support for local procurement

3. Improve food system waste management

a. Other waste management strategies

b. Support for food waste reduction, composting and recovery

c. Support for improved agricultural waste management, reduction, recovery

4. Improve water management in food systems
a. Improve irrigation and drainage infrastructure
b. Support for integrated stormwater management objectives with food systems
c. Support for water conservation /restrictions within food system
d. Support for water rates for agriculture

5. Support for food system education and research

a. Develop and celebrate local food culture

Representation in scanned OCPs (\%)

b. Support and build capacity for public food system education

c. Supprt training and skills development for farmers

d. Support and build capacity for food system research/data collection

6. Support for economic viability of agricultural sector

a. Support for agricultural industry services

b. Support for farm labour

c. Support for farmers to diversify economic opportunities

d. Support for local marketing initiatives

e. Other tools to support economic viability

7. Support for edge planning and urban conflict mitigation

a. Planning and regulation of roads and traffic in farming areas

b. Support for agricultural impact assessment

c. Support for protection of farming development areas

d. Other strategies for agricultural edge planning (e.g. buffers, disclosure agreements)
$22 \%$

$33 \%$

$12 \%$

$67 \%$

$18 \%$

$14 \%$

$10 \%$

$47 \%$

$12 \%$

$12 \%$

$39 \%$

$2 \%$

$35 \%$

$4 \%$

$39 \%$

20\%

$14 \%$

$6 \%$

$4 \%$

$45 \%$

$8 \%$

$37 \%$

$6 \%$

$6 \%$

$61 \%$

$12 \%$

$8 \%$

$35 \%$

$27 \%$

$14 \%$

$55 \%$

10\%

$6 \%$

$20 \%$

$33 \%$

continued 
a. Support for urban livestock

b. Support for commercial urban agriculture

c. Urban gardens/orchards on public land

d. Urban gardens/orchards on private land

e. Urban gardens/orchards non specified land type

f. Other tools to support urban agriculture

9. Support to protect agricultural land/ promote its use for agriculture

a. Address residential development (eg. farm homeplate)

b. Maintain stable ALR boundary and regulation of parcel size

c. Support access to land for farmers

$45 \%$

d. Support agricultural/farmland trusts

$16 \%$

e. Support for regulation of fill deposit

$4 \%$

f. Support for Urban Containment Boundary

$6 \%$

g. Other tools/commitment to protect ag land and promote use for agriculture

10. Support for ecosystem protection/ enhancement in food systems

$31 \%$

a. Commitment to reduce food system impacts on climate change/adapt food systems to climatic changes

b. Support for B.C. Environmental Farm Plan

c. Support for biodiversity and wildlife management/protection

d. Support for ecological production strategies

$12 \%$

e. Other tools for ecosystem management/protection

$24 \%$

11. Support for food system policy partnerships, advocacy and development

$45 \%$

a. Support groups that build food system planning capacity

$10 \%$

b. Support partnerships to achieve food system goals

$31 \%$

c. Commitment to advocate senior gvt to achieve food system goals

12. Support for Indigenous foodways

a. Maintain access to traditional/wild food lands

$6 \%$

b. Support education initiatives for traditional food systems

c. Support collaborative work with First Nations groups

13. Support for food self reliance 